International Journal of Linguistics, Language and Culture (IJLLC)

Journal Homepage: http://ijcu.us/online/journal/index.php/ijllc

Vol. 2, No. 2, July 2016, pp. 53 58

ISSN: 2455-8028 Impact Factor: 2.994

RESEARCHERID

DOI: 10.6084/m9.figshare.3423695 | ORCID: 0000-0001-7224-7481 | Thomson Reuters ID: C-6767-2016 |

\title{
To the Maintenance of Balinese Culture
}

I Ketut Darma Laksana *

Article history:

Received April $5^{\text {th }}, 2016$

Revised June $10^{\text {th }}, 2016$

Approved June $16^{\text {th }}, 2016$

\section{Keywords:}

Culture;

Taboo;

Tourism;

Maintenance;

Balinese.

\begin{abstract}
This paper discusses cultural maintenance and the role of Balinese taboos. Today, the influence of outside societies cannot be avoided because of tourism development in Bali. From the topic concerned, the subjects of the study are taken from professional tourist guides and their family-wives and children. Ideally, Balinese people must be familiar with their own culture and outside societies must be hoped too. However, most of them didn't know clearly what the culture is. Culture must be maintained by people in general because culture is embodied in religion. The problems are: first, what are the conditions that should be understood by the community to maintain the culture? Second, what are the necessary things that should be known by the community to avoid the Balinese taboos? To solve these problems, the research employed with the cognitive approach. By the cognitive approach data are taken from the informant's knowledge. Thus, the research revealed new values toward the understanding of Balinese culture because the information came from the insiders' view.
\end{abstract}

Copyright $@ 2016$ International Journal of College and University. All rights reserved.

Author correspondence:

Article cited by | DOI |Orcid | OAI DOAJ | Thomson Reuters | Scopus |

First Author,

Udayana University, Jalan P.B. Sudirman, Denpasar,

Bali-Indonesia, Email: darmalaksana27@yahoo.com

\section{Introduction}

Balinese culture is very well known all over the world. Rituals, custom, music and performing arts are known as symbol of Balinese culture. This happens not to the Balinese people but also for the outside societies who are aware about the life of the Balinese culture that they are worried if the culture will be getting extinct. Since long time go the people of the island have had contacts with foreigners especially in relation to tourism activities.

According to Sarsito (2006:66), who quotes Spradley and Mc Curdy (1995), this contact can affect cultural changes. If the contact of two different cultures causes some developments, it is positive because a certain culture becomes rich. But, on the contrary, if the contact causes some changes, it is negative because certain culture that adopts, much or less from the other, will endanger the culture itself. In relation to these facts, the problems are: first, what are the conditions that should be understood by the community to maintain the culture? Second, what are the necessary things that should be known by the community to avoid the Balinese taboos? For the first problem, Strauss and Quinn (1994) proposed four conditions that should be preserved by people themselves--that cultural understanding must be: (1) relatively durable in individuals; (2) relatively stable historically, being reproduced from generation to generation; (3) thematic, in the sense that certain understanding may be applied repeatedly in a wide variety of contexts, and (4) more or less

\footnotetext{
* Udayana University, Jalan P.B. Sudirman, Denpasar, Bali-Indonesia
} 
widely shared; in fact, we do not call a cultural understanding unless it is shared, to some extent, in a social group. For the second problem, the role of Balinese taboos must be considered to maintain Balinese culture.

A good example can be given from Lambertz's writing in his book entitled Taboe op Bali (1987:167171). He dealt with his confusion toward the sanction of the Balinese taboo. When he was together with his wife visiting the Pura Kehen, the bigest temple of Bangli region, province of Bali, they shaw "an intention" written on the anouncement: "Entrance forbidden for women during their period", with its translation into Indonesian, which is put in brackets: (Dilarang masuk bagi wanita yang sedang datang bulan). This case will be presented more in the part of Results and Analysis below.

\section{Research Method}

The research was done by using qualitative method which a consists of observation, participant observation, and interview. Observation was done by collecting the data from etic and emic view. The etic view is concerned with knowledge about the Balinese culture that has been possessed by the researcher, whereas the emic view is concerned with knowledge that must be taken from the members of a society (Pike, 1966:153). Douglas (1992:vii) talked about systemic approach that "No parcular set of classifying symbols can be understood in isolation, but there can be hope of making sense of them in relation to the total structures classification in the culture in question". This means that our understanding of the Balinese culture cannot be separated from its custom and religion. Agar (1995:584) also talked about the relation between language and culture: "Language has always been linked to ethnographic research and the cultural representation that is produced". Meyers (cited in Duranti, 1997:92) said that: "For the first time, an ethnographer learns to see and listen. Interactions in daily lives are important in the researcher capability learning to detect the rule of culture ".

Participant observation in this study is characterized by "making response". For example, when someone said, "I will put my shoes on the table", the others might responded, "No, it is forbidden because table is a clear thing, shoes should be put under table or on the floor".

Interview was done during data collections in order to get rich information. It was impossible to understand about the Balinese way of life. For example, "Why does women during their period are forbidden to enter the temple?" From this question, the answer is: "The temple is holy place, and the blood of menstruation is regarded as an unclean thing". It is alright because a temple must maintain its purity all the time.

\section{Results and Analysis}

The results and analysis of the study will be divided into two sections: (1) cultural maintenance, and (2) understanding of the Balinese taboos.

\subsection{Cultural Maintenance}

Firstly, the concept of culture must be explained in order to give the reader an understanding about it. It had been already known that between 1955 and 1960 the human sciences change in a radical way. Before 1955 the dominant paradigm was behaviorism, with its assumption that most things about peoplepersonality, culture and language - could be understood as complexes of stimulus and response connections. In the behavioral tradition, what a creature does is controlled, in large part, by various external conditions. From this point of view the conceptions of culture came to be seen as patterns of behavior. The behaviorist tradition, as we have already known, usually confronted with the cognitive paradigm. In the cognitive paradigm, what a creature does is, in large part, a function of the creature's internal representation of its environment. From this point of view, culture consists not of behavior, or even patterns of behavior, but rather of shared information or knowledge encoded in system of symbols (D'Andrade, 1974:88). In this article I argue that the cognitive paradigm or internal representations has a better fit to ethnographic investigation and theoretical analysis. Since cultural maintenance is related to cultural understanding, I will follow the cognitive paradigm to show what people had done to maintain their culture.

Secondly, culturally constructed things can be seen through Goodenough's writing. Goodenough (1967) has pointed out that the formulation of culture focused on knowledge. This means that society's culture consists of whatever one has to know or believe in order to operate in a manner acceptable to its members. Knowledge, then, typically consists of rules - rules by which one decides where to live, how kin are to be classified, how deference is to be expressed, and so on. The rules by which individuals take as guidance in their everyday interaction become a strong basis for culture maintenance. But, the problem is whether many things one would want to call culture are completely shared? Although not all of members of a society share knowledge about their culture, it can be assumed that one could have a certain personality.

Thirdly, the relation between culture and personality has been discussed by scholars who are interested in both domains. Victor Barnouw (cited in Harris, 1991:266), for example, points out that culture refers to the patterned ways in which the members of population think, feel, and behave. According to him, personality 
also refers to patterned ways of thinking, feeling, and behaving, but the focus is on the individual. Personality, as defined by Barnouw, is a more or less enduring organization or forces within the individual associated with a complex of fairly consistent attitudes, values and modes of perception which account, in past, for the individual's consistency of behavior. More simply, according to Whiting and Whiting, personality is the tendency to behave in certain ways regardless of the specific setting (cited in Harris, 1991: 266).

The implication of those explanations above is that what we can observe from individual behavior is just about their external condition. I believe that the individuals as the member of society are generally having the rules of their culture. Although some of them do not follow the rules in the right way, indeed, they are the belonging of the culture. There is a good example for this point of how people of the North Balinese, i.e. Buleleng regency, province of Bali, exhibit a specific attitude in relation to the using of "swear words" between the individuals in the group, especially for the young generation (Darma Laksana, 2003).

It is important to show that there is a somewhat different approach to culture and personality postulate. Harris (1990:273) stated that every culture produces a basic or deep personality structures that can be found in virtually individual member of the culture. When the populations involved are organized into a state, the basic personality is often called national character. He stated further that the concept of basic personality type must not be permitted to obscure the fact that there is a great range of personalities in every society and that the more populous, complex, and stratified the society, the greater the variability.

Fourth, there are four conditions in culture maintenance. First, cultural understanding must be relatively durable in individuals. Part of the reason why cultural understandings are durable is that these understand ings--and all learning - results in changes in the strength of connections among neurons that are not easily undone. Patterns of neural connections can be overlain with other, stronger, patterns of connections, but they do not completely disappear.

A tourist guide of a Balinese people, for example, can learn to enact new understandings: now that he is an adult, he is able to speak English or other languages for giving some services to his guest tourists, and at home, he and his wife try to share cooking equally. For the first setting, the tourist guide can make enjoyment with his guest long a trip or at an Art Shop. However, he still finds that if he does not make a conscious effort to do otherwise, he tends to drift into the Western thinking such as individualism. For the later, if they do not also make a conscious effort to do otherwise, they tend to drift into the gender roles they observed when they were growing up. When they are busy entertaining, for example, the wife tends to end up in the kitchen while the husband chats with the guests. Thus, he must be conscious with his environment, someday he must join other people for holding the Balinese custom, e.g., the death ceremony. Such strong cognitive patterns cannot simply be erased and replaced with alternative patterns. These become schemas that fit into the individual mind. From these schemas or well-learned understandings supply the interpretations and behaviors that come to the tourist guide automatically; it takes deliberate thought and effort to set up new patterns of behavior.

Second, cultural understanding must be stable historically. The durability of schemas for individuals has consequences for the stability of schemas historically, that is, their reproduction from one generation to another. When people enact the pattern they have learned, they recreate the public world of objects and events from which the next generation learns. For example, when the guide and his wife drift back into gender roles they learned when growing up, their behavior, then, becomes part of the observable world that shapes their children's schemas. Since the guide and his wife have been socialized to value self-reliance in themselves and others, they transmit that value to their children, often using child-rearing practices like the ones through which self-reliance was developed in them. Here they are being an exemplary person to their children.

Third, cultural understanding must be relatively thematic, in the sense that certain understanding may be applied repeatedly in a wide variety of context. Culture can be saved longer if it is applied repeatedly in a wide variety of contexts. A good example for the thematic factor is about purity and pollution in Balinese culture. The concept of purity and pollution in Balinese culture are very important to know in order to avoid something that is forbidden (Darma Laksana, 2003). How to make people aware of those concepts and practices it in appropriate way. Again, the children's parents become an exemplary person for maintaining purity and avoiding pollution.

Since the tourist guide and his wife say "please try to do it yourself nearly every time their children ask for help (unless the obstacle is something that the children are felt to be incapable of overcoming), their children have come to associate of many different sorts with the expectation that they will overcome them in their own. For example, when their children came back from school, they had to put their shoes under the table by their own. The parent just gives some instructions that the table is a clean object, so it must be kept clean. Putting something which is unclean like shoes on the table is not good because it causes pollution.

From experience that occurred repeatedly, the children have schemas by which they behave on the appropriate manner (Wallace, 1981:73). Their new experiences evoke an interpretation based on overall 
similarity of features of the current experiences to repeated or particularly memorable combinations of features of previous experiences. Thus, in the future, any new obstacle that the tourist guide's children experience will evoke their "do it on your own" expectation provided that it has the right sort of family resemblance to previous occasions when they learned to do self-reliance can generalized quite widely across a family of experiences, giving foundation to outside observers' descriptions of national character or the "ethos" of a people (Harris, 1991:273).

Four, cultural understanding must be more or less widely shared; in fact, we do not call like that unless it is shared, to some extent, in a social group. The relation between two phenomena, i.e., public world and private psyches also helps explain why certain schemas are so widely shared in a society. It is not necessary that two people have had exactly the same experiences for them to arrive at some of the same schemas. By adopting connectionist models, the most frequently represented patterns of associations among features are internalized as strong connections, while random variations around the mode are represented by weaker connection weights that have much less effect on cognitive processing. Schema is an abstraction that saves as a basis for organizing information (Cusson, 1981:19).

Thus, in learning the cultural model that self-reliance is good, it does not matter that the tourist guide acquired this understanding from parental homily, A, personal experience B, and travel office $\mathrm{C}$, while the wife acquires it from a different assortment of experiences (see also D'Andrade, 1981: 476). Since both sets of inputs reveal the same general patterning of associated features, that pattern is represented by strongly interconnected units in each of their cognitive networks. This model patterning of experiences can made certain ideologies in order to get self-reliance of the people who belong to the culture

\subsection{Taboo in Balinese Culture}

In this sub section will be given the concept of taboo and the sanction of taboo in Balinese culture. First, the concept of taboo should be understood by people. Taboo is "A prohibition, which, if violated, leads to an automatic penalty inflicted by magic and religion (Winick, 1958:502). Originally, the word taboo (Polinesian: tabu or tapu) was taken by Capt. James Cook in his third journey all over the world, in Tonga, Polinesia island, in 1777.

The basic concept of taboo, that "prohibition" still remains. However, substances, sources, and it sanction changes from culture to culture. In Polinesian, the violation of taboo will be enforced by king, leader, or priest. In another culture it seems to be inflected by God and society. Some others believe that violation leads to an automatic penalty without human or supernatural mediation. In some cultures the sanction enforced by man or member of a society. How about the sanction in Balinese culture?

Second, as has been already quoted above, after reading the announcement, Lambertz and his wife were confused a while what is about the sanction of the Balinese taboo if people violate it. They think how to enter to the temple, may be with buying the canang sari (one of the offering of the Balinese ritual). For the people's understanding like this - they came to the temple without tourist guide — of course, it is not the right one. For the Balinese custom, blood during the period (or menstruation) is regarded as dirty or pollution. In order to enter to the temple, Balinese women must be waiting for a couple of days until the menstruation stops. This means that they are now become a clean or holy person.

If they come to the temple with guiding person who knows about Balinese culture, the above situation does not occur. In this case, the roles of the tourists guide are very important. No matter, whatever the tourist guide's believer, muslem or christiany, they have to know what Balinese culture or religion is.

People are also prohibited to pronounce dirty words in the temple such as swearing words like bloody, fuck you, damn it (Balinese: memisuh). Another thing is taboo of name. For example, the priest (Balinese: pedanda) is prohibited to pronounce his proper name. For the priest, people must pronounce the metonimic name, for example, Pedanda Kemenuh, priest from Kemenuh village, Gianyar region, province of Bali.

\section{Conclusion}

Balinese people who are generally aware of their culture should think that foreign influences are never successful to change other culture unless they have cultural understanding as owner of the culture. Based on the above four conditions, there are no reasons to worry that the Balinese culture will be getting extinct. Thus, cultural understanding is very important and Balinese taboos that must be understood by people.

In the future, Balinese people and outside societies would be familiar toward Balinese culture so that the culture that can be maintained. There are many subjects about Balinese culture that can be studied. With hopefulness that further studies might explore the other subjects in order to give more about Balinese culture.

\section{Acknowledgement}

As a writer on ethno linguistics, we have to try to combine language and culture. For these two subjects, at the beginning, I feel it is hard to understand the interdisciplinary fields. Through to guidance of my professors this constraint can be overcome. They are E.K.M. Masinambow (on language and culture), Benny 
H. Hoed (on semiotics), Anton M. Moeliono (on semantics and figurative language), and Harimurti Kridalaksana (on linguistics method).

This article had been prepared on many years ago after I had obtained my professor at Udayana University in November 6th 2010. I express my gratitude to my colleagues at the Indonesian Departement of Udayana University for their support and my colleagues at the English Department of Udayana University for their guidance on English language so that my English getting progress.

\section{References}

[1] Agar, M. "Ethnography", in Verschueren, J.,et al, Handbook of Pragmatics. Amsterdam: John Benjamin, 1995, pp. $583-590$

[2] Cusson, R.W., ed. 1981. Language, Culture and Cognition. London: Racmillan.

[3] D'Andrade, R.G.W. "Cultural Meaning Systems", in Bulletin of TheAmerican Academy of The Arts and Sciences 28, Number I, 1974, pp. 88--119.

[4] D'Andrade, R.G.W. "Memory and the Assessment of Behavior", in Cusson, ed., Language, Culture and Caguition. London: Macmillan, 1981, pp. 456--480.

[5] Darma Laksana, 1 K. 2003. "Tabu dalam Bahasa Bali" (dissertation). Jakarta: Universitas Indonesia.

[6] Douglas, M. 1992. Purity and Danger: An Analysis of the Concept of Pollution and Taboo. London and New York: Routeledge.

[7] Duranti, A. 1997. Linguistic Anthropology. Cambridge: Cambridge University Press.

[8] Goodenough, W.H. "Toward a Working Theory of Culture". in Borofsky, ed., Assessing Cultural Anthropology. New York: Mc Graw Hill, 1994, pp. 262-- 283.

[9] Harris, M. 1991. Cultural Anthropolog. 3rd Edition. New York: Harfer Collins Publisher.

[10] Lambertz, L., 1987. Taboe op Bali: en andere verhaten over Indonesie. Uitgeverij de Gues, Breda.

[11] Sarsito, T. "Pengembangan Kebudyaan Daerah di Era Kemajuan di Bidang Kepariwisataan". in Dinamika Kebudayaan. Denpasar: Lembaga Penelitian Universitas Udayana, 2006, pp. 65--71.

[12] Strauss, C, and Naomi Quinn. "A Cognitive/Cultural Anthropology", in Borofsky, ed., Assessing Cultural Anthropology. New York: Me Graw Hill, 1994, pp. 284--297.

[13] Wallace, A.F.C. "Culture and Cognition", in: Cusson, ed., Language, Culture and Cognition. London: Macmillan, 1981, pp. $67--74$

[14] Winick, C. 1958. Dictionary of Anthropology. Ames, Iowa: Littlefield, Adams \& Co. 


\section{Biography of Author}

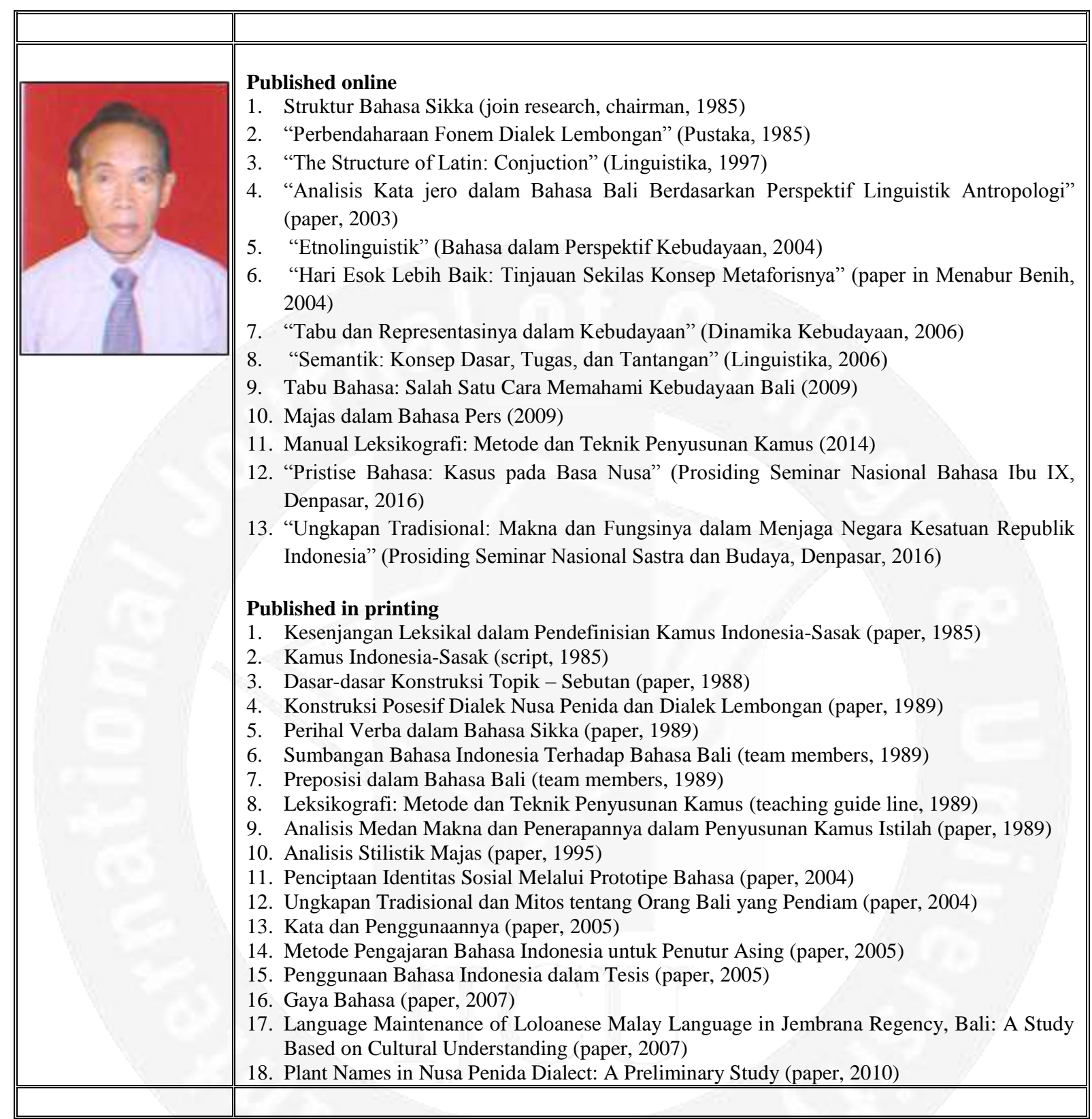

